\title{
Arti Penting Kepuasan Kerja Bagi Apoteker: Antara Bertahan Atau Keluar Dari Pekerjaan
}

Muhammad Khalid Rijaluddin ${ }^{1,2,3}$, Wahyu Utami ${ }^{{ }^{*}}$, Zulhabri Othman ${ }^{2}$, Eddy Yusuf ${ }^{2}$, Hanni Prihhastuti Puspitasari ${ }^{1}$, Andi Hermansyah ${ }^{1}$

${ }^{1}$ Fakultas Farmasi, Universitas Airlangga, Surabaya, Indonesia

${ }^{2}$ Post-Graduate Centre, Management and Science University, Shah Alam, Malaysia

${ }^{3}$ Dinas Kesehatan Kabupaten Kediri, Kediri, Indonesia

*Corresponding author: wahyu-u@ @ff.unair.ac.id

Submitted: 21 November 2020

Accepted: 31 December 2021

Published: 09 April 2021

\begin{abstract}
Background: Community pharmacist plays a significant role in public health. The increasing number of pharmacies in tandem with the rising demand for pharmaceutical services have presented sheer pressure for pharmacist to practice. Accordingly, exploring pharmacist satisfaction is critical to evaluate the quality of pharmacist services and its implication with the intention to leave the current job position. Objective: To analyze the factors affecting job satisfaction and career of pharmacists and their intention to leave their current job. Methods: This is a cross-sectional study using online-based questionnaire administered to the community pharmacist. The survey was conducted from December 2019 to February 2020. Data was analyzed using Structural Equation Modeling Partial Least Squares (SEM-PLS) Results: There were 292 pharmacists participated in this study. Most of them were female (77.39\%) with working experience of less than 5 years (51.03\%). The results showed that both extrinsic and intrinsic factors affect satisfaction (3.120 and 4.981), while the intention to leave was only influenced by extrinsic factor (1.974). Characteristics of respondent also affected the intention to leave (3.929). Conclusion: Extrinsic and intrinsic factors affect pharmacist satisfaction, but only extrinsic factors influence on the intention to leave.
\end{abstract}

Key words: pharmacist, pharmacist satisfaction, intention to leave

\begin{abstract}
Abstrak
Pendahuluan: Apoteker di komunitas merupakan elemen penting dalam kesehatan masyarakat. Semakin meningkatnya jumlah apotek ditambah dengan tingginya permintaan masyarakat terhadap layanan kefarmasian yang berkualitas menyebabkan tekanan yang besar kepada praktek apoteker. Alhasil, kepuasan apoteker menjadi titik kritis untuk mengevaluasi kualitas pelayanan farmasi dan imbasnya terhadap keinginan untuk keluar atau bertahan dari pekerjaan saat ini. Tujuan: Untuk menganalisis faktor-faktor yang mempengaruhi kepuasan kerja dan karir apoteker serta niat mereka untuk meninggalkan pekerjaan saat ini. Metode: Penelitian ini merupakan penelitian lintang potong dengan menggunakan kuesioner online dan melibatkan apoteker di komunitas sebagai responden. Data kemudian dianalisis menggunakan Structural Equation Modelling Partial Least Squares (SEM-PLS) Hasil: Terdapat 292 apoteker berpartisipasi dalam penelitian ini. Sebagian besar adalah perempuan (77,39\%) dengan pengalaman kerja kurang dari 5 tahun (51,03\%). Hasil dari analisis data menunjukkan bahwa faktor ekstrinsik dan instrinsik mempengaruhi kepuasan kerja apoteker (3,120 dan 4,981), sedangkan pada aspek niat meninggalkan pekerjaan (intention to leave) hanya dipengaruhi secara signifikan oleh faktor ekstrinsik $(1,974)$. Karakteristik responden hanya berpengaruh signifikan terhadap niat untuk meninggalkan pekerjaan $(3,929)$. Sementara itu, kepuasan kerja berpengaruh pada niat meninggalkan pekerjaan $(4,083)$. Kesimpulan: Faktor ekstrinsik dan intrinsik mempengaruhi kepuasan apoteker, tetapi hanya faktor ekstrinsik yang mempengaruhi niat untuk pergi.
\end{abstract}

Kata kunci: apoteker, kepuasan apoteker, niat untuk meninggalkan pekerjaan 


\section{PENDAHULUAN}

Banyak penelitian di bidang manajemen organisasi dan sumber daya manusia menyatakan bahwa keinginan/niat seseorang untuk keluar dari pekerjaan merupakan masalah kritis bagi perkembangan suatu organisasi (Shah \& Beh, 2016; Thakur \& Bhatnagar, 2017; Omar dkk., 2018; Aburumman dkk., 2020). Niatan seseorang untuk meninggalkan pekerjaan tergantung pada dua aspek: keinginan pribadi atau keinginan organisasi. Dalam kasus niatan ditentukan oleh keinginan pribadi maka seseorang dapat keluar dari pekerjaan misalnya jika dia mendapatkan pekerjaan baru yang lebih menarik daripada pekerjaan saat ini. Niatan keluar juga dipengaruhi oleh keinginan organisasi khususnya terkait sistem mutasi dan penempatan posisi. Misalnya ketika seseorang dimutasi pada posisi yang kurang menarik daripada posisi saat ini maka niatan untuk keluar dari pekerjaan bisa muncul (Xu dkk., 2018).

Keinginan untuk meninggalkan pekerjaan juga dapat muncul pada apoteker. Apoteker merupakan tenaga sentral dalam pelayanan kefarmasian. Perkembangan dunia kefarmasian yang begitu cepat terkadang membuat apoteker melakukan pekerjaannya dalam tekanan. Hal ini juga terjadi pada apoteker di komunitas, dinamika perubahannya begitu terasa dan cepat (Athiyah \& Hermansyah, 2019). Apoteker di komunitas menjadi ujung terdepan dalam pelayanan farmasi yang berhubungan dengan masyarakat. Perubahan orientasi layanan, yang dahulu hanya didasarkan pada layanan berbasis produk (drugs oriented) menjadi berbasis pada pada pasien (patient oriented) (Hermansyah dkk., 2016). Dalam beberapa tahun terakhir, keterlibatan apoteker dalam perawatan pasien (patient care) meningkat secara signifikan. Hal ini tidak terlepas dari perkembangan layanan apoteker yang sebelumnya hanya berfokus pada penyiapan dan dispensing sediaan farmasi menuju ke bentuk hubungan apoteker dan pasien sebagai konsultan obat (drug advicer) (Hassali dkk., 2015; King dkk., 2012).

Praktik kefarmasian di Indonesia mengalami perubahan yang mendasar ketika Sistem Jaminan Kesehatan Nasional (JKN) mulai tahun 2014 dimulai (Depkes RI, 2014). Apotek yang menjadi sarana praktek apoteker di komunitas hanya sedikit yang menjadi mitra dalam Sistem JKN (Hermansyah dkk., 2018). Sedangkan sebagian besar lainnya belum menjadi bagian dari sistem JKN. Terdapat variasi apotek yang beragam mulai dari apotek milik perseorangan, apotek jaringan baik swasta maupun milik BUMN maupun apotek yang hasil kerja sama apoteker dengan pemilik modal yang lebih umum disebut sebagai pemilik sarana apotek (PSA). Hal ini semakin meningkatkan tekanan kepada apoteker.

Disamping itu, rekognisi Apoteker di komunitas juga masih sangat kecil termasuk sedikitnya peluang untuk jenjang karir (Farris dkk., 2005; Carvajal dkk., 2018; Iorga dkk., 2017; Janahiraman \& Paraidathathu, 2007) dan kesempatan yang sangat terbatas untuk mengikuti pendidikan berkelanjutan (Continuing Education) (Mcmillan dkk., 2014; Mihm dkk., 2011) dibandingkan apoteker di setting pekerjaan lain seperti di Rumah Sakit dan Industri. Apoteker di komunitas maupun rumah sakit masih mendapatkan remunerasi dari sisi gaji/pendapatan yang masih rendah dibandingkan dengan tenaga kesehatan lain. Hal ini seharusnya tidak terjadi dikarenakan tanggung jawab yang begitu besar dari apoteker di komunitas maupun di rumah sakit (Nyame-Mireku, 2012; Phua dkk., 2017).

Besarnya tanggung jawab dan adanya celah antara atribut ideal seorang apoteker dengan kenyataan yang dihadapi dapat mempengaruhi penilaian apoteker terhadap pekerjaannya. Beberapa fakta menunjukkan bahwa $48 \%$ apoteker di Malaysia tidak puas dengan pekerjaannya (Sains, 2012). Kondisi yang lebih besar ditemukan di Indonesia antara lain $81,81 \%$ apoteker merasa kurang puas dan tidak puas terhadap pekerjaannya di suatu rumah sakit swasta ternama di Surabaya (Karina, 2011).

Istilah kepuasan kerja apoteker mengacu pada sikap umum individu terhadap pekerjaannya. Menurut teori Herzberg, kepuasan dan ketidakpuasan kerja memiliki hubungan independent satu sama lain (Herzberg, 1966). Kepuasan dimaksudkan sebagai kurangnya ketidakpuasan dan sebaliknya, ketidakpuasan bukanlah kebalikan dari kepuasan tetapi kurangnya kepuasan. Seseorang dengan tingkat kepuasan kerja yang tinggi memiliki sikap positif terhadap pekerjaan itu, sementara orang yang tidak puas akan memiliki sikap negatif tentang pekerjaan itu. Kepuasan kerja atau ketidakpuasan kerja apoteker memainkan peran utama dalam banyak aspek pekerjaan termasuk dalam praktik kefarmasian. Berbagai faktor mempengaruhi kepuasan dan ketidakpuasan apoteker antara lain: kebijakan dan administrasi, supervisi, jasa profesi, hubungan antar pribadi, kondisi kerja, keberhasilan, pengakuan, pekerjaan itu sendiri dan tanggung jawab. Ketidakpuasan dalam bekerja akan berimbas antara lain pada kinerja ketidak-hadiran atau kemangkiran dalam bekerja dan keinginan keluar dari pekerjaan saat 
ini maupun berpindah pekerjaan (Nyame-Mireku, 2012; Seston dkk., 2009).

Kepuasan dan ketidakpuasan apoteker di apotek haruslah menjadi perhatian serius. Hal ini dikarenakan besarnya jumlah apotek di Indonesia. Sebagai contoh, pada tahun 2018 terdapat sebesar 26.658 apotek dengan 3.674 apotek diantaranya berada di Jawa Timur (Dirjen Farmalkes, 2020; Simada Binfar, 2020). Besarnya jumlah apotek tentu merepresentasikan wajah profesi apoteker di Indonesia. Oleh karena itu, perlu dilakukan penelitian untuk mengetahui faktor-faktor kepuasan apoteker dan niatan meninggalkan pekerjaan sebagai Apoteker Penanggung Jawab Apotek.

\section{METODE}

\section{Rancangan penelitian}

Penelitian ini merupakan penelitian kuantitaf cross-sectional dengan menggunakan survei kuesioner. Kuesioner dirancang menggunakan e-form yang disediakan oleh https://www.surveymonkey.com dan disebarkan melalui pesan elektonik via whatsapp messenger.

\section{Populasi dan sampel}

Populasi dalam penelitian ini adalah seluruh Apoteker Penanggung Jawab (APJ) Apotek di Propinsi Jawa Timur dengan jumlah sedikitnya 3,600 apoteker.

\section{Teknik pengambilan sampel}

Dalam penelitian ini menggunakan teknik accidental sampling.

\section{Variabel penelitian}

Terdapat 3 variabel dalam penelitian ini (Gambar 1) yaitu variabel bebas, variabel mediasi dan variabel terikat. Variabel bebas dalam penelitian ini terdiri dari 3 sub-variabel antara lain: (1) faktor Ekstrinsik terdiri dari Policy and Administration, Supervision, Proffesional Fee, Interpersonal Relationship, Physical Working Conditions, Workload, (2) faktor Intrinsik yaitu : Achievement, Promotion, Recognition, Work it Self, Responsibility, Growth dan (3) karakteristik responden yang mencerminkan profil apoteker seperti demografi (Usia, Pendidikan terakhir, Total pendapatan, Jenis kepemilikan, Jenis pengelolaan, Tahun lulus, Lama menjadi APJ Apotek, Rentang Jarak, Durasi Lama praktek). Ketiga sub variabel tersebut dikembangkan dari teori dua faktor kepuasan kerja oleh Herzberg (1996). Kepuasan apoteker menjadi variabel mediasi dan keinginan keluar dari pekerjaan adalah variabel terikatnya.

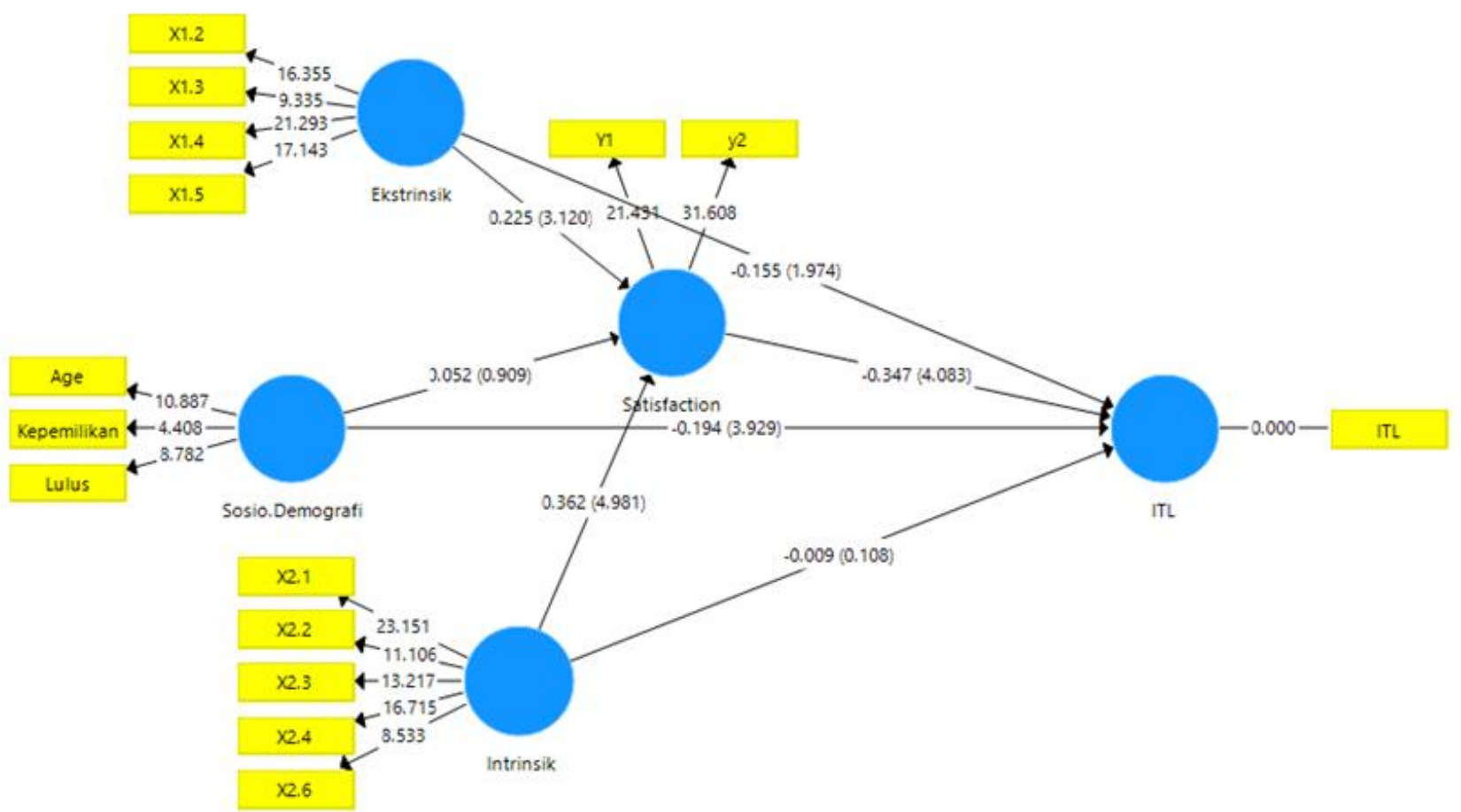

Gambar 1. Koefisien jalur dan nilai $\mathrm{R}^{2}$ untuk model penelitian

\section{Instrumen penelitian}

Instrumen penelitian ini adalah kuesioner berbasis survei online, menggunakan website https://www.surveymonkey.com. Link kuesioner didistribusikan melalui WhatsApp Group Pengurus Daerah Ikatan Apoteker Indonesia (IAI) Jawa Timur 
dan Pengurus Cabang IAI Kab/Kota di Jawa Timur. Instrumen terdiri dari dua bagian, yaitu kuesioner tentang karakteristik responden dan kuesioner tentang faktor ekstrinsik, faktor intrinsik, satisfaction dan intention to leave. Kuesioner menggunakan 4 skala likert yang terdiri dari sangat tidak setuju; tidak setuju; setuju; dan sangat setuju.

\section{Analisis statistik}

Analisis deskripsi dilakukan untuk memberikan Gambaran data karakteristik responden Apoteker yang berpraktik di Apotek. Sedangkan analisis menggunakan Structural Equation Modelling Partial Least Squares (SEM-PLS) untuk penilaian model pengukuran dan model struktural. Metode SEM-PLS dipilih untuk menganalisis data yang sifatnya prediktif dengan asumsi teori yang masih lemah, atau data bersifat kompleks (melibatkan banyak variable independent) dengan konstruk atau model yang masih lemah. Sebelum dilakukan penilaian model pengukuran dan model struktural dilakukan uji validitas dan reliabilitas terlebih dahulu. Validitas konvergen diukur menggunakan nilai outer loading sedangkan validitas diskriminan diukur menggunakan nilai Cross Loading indikator terhadap masing-masing variabel laten. Untuk mengetahui akurasi, konsistensi dan ketepatan instrument dalam mengukur konstruk dapat dilakukan dengan melihat composite reliability. Konstruk dinyatakan reliable jika nilai composite reliability di atas 0,70 .

\section{Lokasi dan waktu penelitian}

Lokasi yang akan digunakan dalam penelitian ini adalah Apotek di provinsi Jawa Timur. Waktu pengambilan data dilakukan pada bulan Desember 2019 sampai dengan Januari 2020. Penelitian ini telah mendapatkan persetujuan laik etik dari Komisi Etik Penelitian Kesehatan Fakultas Farmasi Universitas Airlangga No.04/LE/2020.

\section{HASIL DAN PEMBAHASAN}

Terdapat 292 APJ yang berpartisipasi dalam penelitian ini. Karakteristik responden ditampilkan pada Tabel 1 .

Tabel 1. Karakteristik responden

\begin{tabular}{|c|c|c|}
\hline Karakteristik Responden & Jumlah (n) & Persentase $(\%)$ \\
\hline \multicolumn{3}{|l|}{ Jenis Kelamin $(n=292)$} \\
\hline Laki-laki & 66 & 22,60 \\
\hline Perempuan & 226 & 77,39 \\
\hline \multicolumn{3}{|l|}{ Usia (tahun) $(\mathrm{n}=292)$} \\
\hline$\leq 31$ tahun & 142 & 48,63 \\
\hline$>31$ tahun & 150 & 51,37 \\
\hline \multicolumn{3}{|l|}{ Pendidikan terakhir $(\mathrm{n}=292)$} \\
\hline Apoteker & 267 & 91,44 \\
\hline Apoteker + Pascasarjana & 25 & 8,56 \\
\hline \multicolumn{3}{|l|}{ Jenis Kelamin $(n=292)$} \\
\hline Laki-laki & 66 & 22,60 \\
\hline Perempuan & 226 & 77,39 \\
\hline \multicolumn{3}{|l|}{ Usia (tahun) $(\mathrm{n}=292)$} \\
\hline$\leq 31$ tahun & 142 & 48,63 \\
\hline$>31$ tahun & 150 & 51,37 \\
\hline \multicolumn{3}{|l|}{ Pendidikan terakhir $(\mathrm{n}=292)$} \\
\hline Apoteker & 267 & 91,44 \\
\hline Apoteker + Pascasarjana & 25 & 8,56 \\
\hline \multicolumn{3}{|l|}{ Total pendapatan yang di terima $(n=292)$} \\
\hline$\leq$ Rp. $3.000 .000,00$ & 127 & 43,49 \\
\hline Rp. 3.000.001,00 - Rp. 5.000.000,00 & 125 & 42,81 \\
\hline$>$ Rp. $5.000 .000,00$ & 40 & 13,70 \\
\hline \multicolumn{3}{|l|}{ Jenis kepemilikan Apotek $(\mathrm{n}=292)$} \\
\hline Apotek Milik sendiri (Modal sendiri) & 65 & 22,26 \\
\hline Apotek Kerjasama (Modal Pihak lain) & 227 & 77,74 \\
\hline \multicolumn{3}{|l|}{ Jenis Pengelolaan berdasarkan pemodalan $(n=227)$} \\
\hline Apotek Milik Pemodal (PSA) Perseorangan & 178 & 78,42 \\
\hline Apotek Milik Pemodal (PSA) Perusahaan & 26 & 11,45 \\
\hline Apotek Milik Pemodal (PSA) dibawah Yayasan/Koperasi & 13 & 5,73 \\
\hline Apotek Franchise/Waralaba & 6 & 2,64 \\
\hline Model kerjasama lain & 4 & 1,76 \\
\hline
\end{tabular}




\begin{tabular}{lcc}
\hline Tahun Lulus $(\mathrm{n}=292)$ & & \\
$<2010$ & 123 & 42,12 \\
$>2010$ & 169 & 57,88 \\
\hline Lama menjadi APJ Apotek $(\mathrm{n}=292)$ & & \\
$<5$ tahun & 149 & 51,03 \\
$5-10$ tahun & 74 & 25,34 \\
$>10$ tahun & 69 & 23,63 \\
\hline Rentang Jarak dari tempat tinggal ke apotek $(\mathrm{n}=292)$ & & \\
$0 \mathrm{~km}-5 \mathrm{~km}$ & 173 & 59,25 \\
$5,01 \mathrm{~km}-23 \mathrm{~km}$ & 94 & 32,19 \\
$>23 \mathrm{~km}$ & 25 & 8,56 \\
\hline Durasi Lama Praktek per pekan $(\mathrm{n}=292)$ & & \\
$<35$ jam/pekan & 95 & 32,53 \\
35 jam/pekan -55 jam/pekan & 99 & 33,91 \\
$>55$ jam/pekan & 98 & 33,56 \\
\hline
\end{tabular}

Pada analisis SEM-PLS menggunakan software SmartPLS (versi 3.2.8) dilakukan penilaian model pengukuran dan model struktural. Validitas dan reliabilitas model pengukuran dapat dibuktikan dari validitas konvergen, validitas diskriminan dan nilai komposit reliabilitasnya. Tabel 2 menunjukkan hasil validitas konvergen yang menunjukkan bahwa alpha dan komposit reliabilitas mencapai nilai yang lebih besar dari nilai ambang yang diusulkan yaitu 0,60 hingga 0,70 . Selain itu, nilai tersebut lebih besar daripada semua variabel (Hair dkk., 2019). Mengenai rata-rata varian yang diekstraksi (AVE), semua variabel mencapai nilai yang lebih besar dari nilai ambang batas yang diusulkan yaitu 0,50 oleh (Hair dkk., 2019). Semua item memiliki nilai outer loading antara 0,629-0,862 kecuali pada variabel karakteristik (Pendidikan terakhir, Total pendapatan, Jenis pengelolaan, Lama menjadi APJ Apotek, Rentang Jarak, Durasi Lama praktek), pada variabel faktor ekstrinsik (Policy and Administration dan workload) dan variabel faktor instrinsik (Responsibility) yang mempunyai nilai outer loading kurang dari 0,50 sehingga dihapus.

Tabel 2 menunjukkan hasil validitas konvergen dan reliabilitasnya. Dari Tabel diketahui bahwa semua indikator memenuhin nilai minimal outer loading $>0,5$ dan nilai composite reliability-nya $>0,7$.

Tabel 2. Validitas konvergen

\begin{tabular}{|c|c|c|c|c|}
\hline Variabel & Item & Outer Loading & $\begin{array}{l}\text { Composite } \\
\text { Reliability }\end{array}$ & AVE \\
\hline \multirow[t]{3}{*}{ Karakteristik } & Usia & 0,819 & 0,823 & 0,615 \\
\hline & Jenis kepemilikan & 0,573 & & \\
\hline & Tahun Lulus & 0,807 & & \\
\hline \multirow[t]{4}{*}{ Faktor ekstrinsik } & Supervision & 0,744 & 0,824 & 0,541 \\
\hline & Proffesionlal Fee & 0,624 & & \\
\hline & Interpersonal Relationship & 0,718 & & \\
\hline & Physical Working Conditions & 0,771 & & \\
\hline \multirow[t]{5}{*}{ Faktor Instrinsik } & Achievement & 0,756 & 0,833 & 0,500 \\
\hline & Promotion & 0,629 & & \\
\hline & Recognition & 0,662 & & \\
\hline & Work it self & 0,719 & & \\
\hline & Growth & 0,661 & & \\
\hline \multirow[t]{2}{*}{ Kepuasan } & $\mathrm{Z1}$ & 0,821 & 0,829 & 0,709 \\
\hline & $\mathrm{Z2}$ & 0,862 & & \\
\hline Intention to Leave & $\mathrm{Y}$ & 1,000 & 1,000 & 1,000 \\
\hline
\end{tabular}

Tabel 3 menunjukkan hasil dari perhitungan validitas diskriminan. Jika korelasi antara indikator dengan variabel laten lebih besar dari pada korelasi variabel laten lainnya maka variabel laten tersebut dapat dikatakan memprediksi indikatornya lebih baik dari pada variabel lainnya. Berdasarkan penilaian hasil validitas konvergen, validitas diskriminan dan nilai composite reliability maka model pengukuran untuk penelitian ini adalah valid dan reliabel. 
Tabel 3. Validitas diskriminan

\begin{tabular}{cccccc}
\hline Indikator/Variabel & Karakteristik & Faktor Ekstrinsik & Faktor Intrinsik & Kepuasan & $\begin{array}{c}\text { Intention To } \\
\text { Leave }\end{array}$ \\
\hline Umur & $\mathbf{0 , 8 8 1}$ & 0,111 & 0,090 & 0,132 & $-0,214$ \\
Jenis kepemilikan & $\mathbf{0 , 5 9 5}$ & 0,113 & 0,129 & 0,079 & $-0,209$ \\
Tahun Lulus & $\mathbf{0 , 8 4 5}$ & 0,040 & 0,052 & 0,063 & $-0,162$ \\
\hline $\begin{array}{c}\text { Supervision } \\
\text { Professional Fee }\end{array}$ & 0,122 & $\mathbf{0 , 7 5 3}$ & 0,339 & 0,231 & $-0,313$ \\
Interpersonal & 0,109 & $\mathbf{0 , 6 4 0}$ & 0,287 & 0,295 & $-0,227$ \\
Relationship & & $\mathbf{0 , 7 6 6}$ & 0,519 & 0,434 & $-0,197$ \\
Physical Working & 0,110 & & & & $-0,270$ \\
Conditions & 0,081 & $\mathbf{0 , 7 7 4}$ & 0,582 & 0,335 & $-0,174$ \\
\hline Achievement & 0,053 & 0,446 & $\mathbf{0 , 7 8 4}$ & 0,435 & $-0,122$ \\
Promotion & 0,123 & 0,434 & $\mathbf{0 , 6 7 1}$ & 0,200 & $-0,230$ \\
Recognition & 0,005 & 0,375 & $\mathbf{0 , 7 0 6}$ & 0,350 & $-0,119$ \\
Work itself & 0,142 & 0,480 & $\mathbf{0 , 7 4 3}$ & 0,397 & $-0,359$ \\
Growth & 0,163 & 0,420 & $\mathbf{0 , 6 2 1}$ & 0,326 & $-0,293$ \\
\hline Z1 & 0,051 & 0,340 & 0,414 & $\mathbf{0 , 8 2 0}$ & $-0,447$ \\
Z2 & $-0,257$ & $-0,339$ & 0,432 & $\mathbf{0 , 8 6 3}$ & $-0,444$ \\
\hline Y & & $-0,299$ & $\mathbf{1 , 0 0 0}$ \\
\hline
\end{tabular}

Pada Tabel 4, nilai $\mathrm{R}^{2}$ kepuasan karyawan sebesar 0.289 (lemah), sedangkan nilai $\mathrm{R}^{2}$ keinginan untuk keluar sebesar 0,289 (lemah). Hal ini berarti bahwa variabel satisfaction dan intention to leave termasuk dalam kategori lemah $\left(0,25<\mathrm{R}^{2}<0,50\right)$. Hal ini menjelaskan bahwa pengaruh variabel laten ekstrinsik terhadap variabel laten edogen kepuasan dan keinginan untuk keluar mempunyai pengaruh substantif yang lemah. Karena itu, model "kepuasan" dan "keinginan untuk keluar" dalam penelitian ini memiliki daya prediksi lemah sesuai dengan nilai $\mathrm{R}^{2}$.

Pada penelitian sebelumnya ditemukan 22 hambatan dalam berpraktek yang mempengaruhi kepuasan apoteker terhadap pekerjaannya (Rijaluddin $\mathrm{dkk}$, 2020). Hambatan tersebut dapat muncul dari individu apoteker, manajemen layanan dan kondisi lingkungan kerja. Hal ini membuat model struktural dalam penelitian memiliki pengaruh substantif yang lemah dikarenakan besarnya dimensi yang belum berhasil digambarkan.

Selanjutnya dilakukan pengujian terhadap model menggunakan algoritma $P L S$ yang disematkan dengan SmartPLS (versi 3.2.8). Kemudian, koefisien jalur dibuat (lihat Gambar 1). Teknik bootstrap yang disematkan dengan SmartPLS (versi 3.2.8) digunakan untuk menyimpulkan apakah koefisien jalur signifikan secara statistik atau tidak signifikan. Tabel 5 menunjukkan $P$-values dan $T$-values yang menyertai setiap koefisien jalur. Hasil model struktural ditunjukkan pada Tabel 5.

Tabel 4. Nilai $\mathrm{R}^{2}$

\begin{tabular}{ccc}
\hline Variabel/dimensi & $\mathbf{R}^{\mathbf{2}}$ & Kriteria \\
\hline Kepuasan & 0,289 & Lemah \\
Intention to Leave & 0,259 & Lemah \\
\hline
\end{tabular}

Tabel 5. Hasil model struktural

\begin{tabular}{llllllc}
\hline No & Hipotesis & Path Coefficient & Standard Error & Nilai T & Nilai P & Kesimpulan \\
\hline H1 & FE $\rightarrow$ Ke & 0,225 & 0,072 & 3,120 & 0,002 & Didukung \\
H2 & FI $\rightarrow$ Ke & 0,362 & 0,073 & 4,981 & 0,000 & Didukung \\
H3 & Ka $\rightarrow$ Ke & 0,052 & 0,058 & 0,909 & 0,364 & Tidak Didukung \\
H4 & FE $\rightarrow$ ITL & $-0,155$ & 0,079 & 1,974 & 0,049 & Didukung \\
H5 & FI $\rightarrow$ ITL & $-0,009$ & 0,079 & 0,108 & 0,914 & Tidak Didukung \\
H6 & Ka $\rightarrow$ ITL & $-0,194$ & 0,049 & 3,929 & 0,000 & Didukung \\
H7 & Ke $\rightarrow$ ITL & $-0,347$ & 0,085 & 4,083 & 0,000 & Didukung \\
\hline
\end{tabular}

* Note: FE = Faktor ekstrinsik; FI = Faktor Instrinsik; Ke = Kepuasan apoteker; ITL = intention to leave;

$\mathrm{Ka}=$ Karakteristik 


\section{Kepuasan Apoteker}

Seperti yang ditunjukkan pada Tabel 5, faktor ekstrinsik $(\beta=0,225 ; \mathrm{T}$-Value $=3,120 ; P$-value $=$ $0,002)$ dan faktor instrinsik $(\beta=0,362 ; T$-value $=4,981$; $P$-value $=0,000)$ memiliki efek langsung positif terhadap kepuasan apoteker di apotek. Hasil ini sesuai dengan yang dilaporkan peneliti sebelumnya (Cavaco \& Krookas, 2014; Cox \& Fitzpatrick, 1999; Iqbal dkk., 2020; Munger dkk., 2013; Murawski dkk., 2008; Nilugal dkk., 2016; Olson \& Lawson, 1996) yaitu faktor ekstrinsik dan instrinsik berpengaruh pada kepuasan dalam bekerja. Dari nilai T bisa disebutkan bahwa faktor instrinsik memiliki pengaruh lebih besar dibandingkan faktor ekstrinsik. Hal iniberbeda dengan temuan di Malaysia dan Pakistan yang menyebutkan faktor ekstrinsik lebih berpengaruh terhadap kepuasan di setting apotek dibandingkan dengan faktor instinsik (Bayarçelik \& Findikli, 2016; Schafheutle dkk., 2009; Seston dkk., 2009). Hal yang sama juga terjadi di setting rumah sakit bahwasanya faktor ekstrinsik lebih dominan (Nyame-Mireku, 2012; Ralph \& Langenbach, 1987).

Sedangkan karakteristik responden tidak berpengaruh kepada kepuasan apoteker $(\beta=0,052$; $T$-value $=0,909 ; P$-value $=0,364)$. Hal ini berbeda dengan temuan beberapa penelitian dimana jenis kelamin apoteker mempengaruhi kepuasan apoteker (Hassell dkk., 2007; Seston dkk., 2009).

\section{Niatan meninggalkan pekerjaan}

Berdasar hasil analisis ditemukan bahwa hanya faktor ekstrinsik ( $\beta=-0,115 ; T$-value $=1,974 ; P$-value $=0,049)$ dan karakteristik $(\beta=-0,194 ; T$-value $=3,929$; $P$-value $=0,000)$ yang mempengaruhi niatan APJ untuk meninggalkan pekerjaanya. Hasil ini menandakan bahwa keinginan apoteker meninggalkan pekerjaan lebih dipengaruhi oleh faktor-faktor luar dibandingkan faktor dari diri apoteker. Disamping itu, karakteristik responden apoteker yang terdiri dari usia, tahun lulus dan jenis kepemilikan berpengaruh negatif pada keinginan meninggalkan pekerjaan. Hal ini berarti bahwa semakin bertambah usia apoteker maka kecenderungan apoteker akan berkurang untuk meninggalkan pekerjaannya. Dalam arti yang berbeda, makin lama masa praktek membuat apoteker menemukan kenyamanan dalam menjalani pekerjaannya.

Kepuasan apoteker berpengaruh negatif terhadap niatan meninggalkan pekerjaanya. Dengan kata lain, semakin puas apoteker terhadap pekerjaan dan karir mereka maka akan mengurangi niatan meninggalkan pekerjaan. Hal ini ditunjukkan pada nilai di Tabel 5 dengan nilai $\beta=-0,347 ; T$-value $=4,083 ; P$-value $=$ 0,000 . Hasil ini selaras dengan temuan Nyame-mireku (2012) bahwa kepuasan apoteker diberbagai setting pekerjaan menurunkan niatan untuk meninggalkan pekerjaan (Mott dkk., 2004; Nyame-Mireku, 2012; Schommer dkk., 2018). Penelitian sebelumnya melaporkan hubungan negatif yang konsisten antara turnover dan kepuasan kerja (Bayarçelik \& Findikli, 2016; Schafheutle dkk., 2009; Seston dkk., 2009). Niat untuk berhenti telah lama diakui mungkin sebagai indikator terakhir dan kuat untuk keluar dari pekerjaanya setelah mengalami ketidakpuasan kerja (Nyame-Mireku, 2012; Ralph \& Langenbach, 1987). Herzberg (1966) menemukan adanya keinginan karyawan untuk keluar dan keputusan keluar dari pekerjaannya saat ini dikarenakan mereka mengalami ketidakpuasan kerja.

\section{KESIMPULAN}

Penelitian ini bertujuan untuk mengetahui pengaruh faktor-faktor yang mempengaruhi kepuasan apoteker terhadap niatan meninggalkan pekerjaan sebagai Apoteker Penanggung Jawab (APJ) Apotek di Jawa Timur. Hasil penelitian ini menunjukkan bahwa ada dua faktor yang mempengaruhi kepuasan kerja yaitu faktor ekstrinsik dan faktor instrinsik. Namun demikian, hanya faktor ekstrinsik saja yang berpengaruh pada keinginan sesorang unutuk meninggalkan pekerjaan.

\section{UCAPAN TERIMAKASIH}

Artikel ini telah dipaparkan pada kegiatan seminar nasional dan temu ilmiah di Fakultas Farmasi Universitas Airlangga tanggal 26 September 2020.

\section{DAFTAR PUSTAKA}

Aburumman, O., Salleh, A., Omar, K. \& Abadi, M. (2020). The Impact of Human Resource Management Practices and Career Satisfaction on Employee's Turnover Intention. Management Science Letters; 10; 641-652.

Athiyah, U. \& Hermansyah, A. (2019). Assessment of Pharmacists' Knowledge, Attitude and Practice in Chain Community Pharmacies Towards Their Current Function and Performance in Indonesia. Pharmacy Practice (Granada); 17; 1-7.

Bayarçelik, E. B. \& Findikli, M. A. (2016). The Mediating Effect of Job Satisfaction on the Relation between Organizational Justice Perception and Intentiom to Leave. Procedia -Social and Behavioral Sciences; 235; 403-411. 
Carvajal, M. J., Popovici, I. \& Hardigan, P. C. (2018). Gender Differences in the Measurement of Pharmacists' Job Satisfaction. Human Resources for Health; 16; 1-8.

Cavaco, A. M. \& Krookas, A. A. (2014). Community Pharmacies Automation: Any Impact on Counselling Duration and Job Satisfaction?. International Journal of Clinical Pharmacy; 36; 325-335.

Cox, E. R. \& Fitzpatrick, V. (1999). Pharmacists' Job Satisfaction and Perceived Utilization of Skills. American Journal of Health-System Pharmacy; 56; 1733-1737.

Depkes RI. (2014). Peraturan Menteri Kesehatan Republik Indonesia No. 35 Tahun 2014 tentang Standar Pelayanan Kefarmasian di Apotek. Jakarta: Depkes RI.

Dirjen Farmalkes (2020). Grafik Rekapitulasi Apotek http://farmalkes.kemkes.go.id/2013/10/grafik-re kapitulasi-apotek/. Accessed: 15 Januari 2020.

Farris, K. B., Fernandez-Llimos, F. \& Benrimoj, S. I. (2005). Pharmaceutical Care in Community Pharmacies: Practice and Research From Around the World. Annals of Pharmacotherapy; 39; 1539-1541.

Hair, Joe F, Risher, J. J., Sarstedt, M. \& Ringle, C. M. (2019). The Results of PLS-SEM Article Iinformation. European Business Review; 31; 224.

Hassell, K., Seston, E. \& Shann, P. (2007). Measuring Job Satisfaction of UK Pharmacists: a Pilot Study. International Journal of Pharmacy Practice; 15; 259-264.

Hassali, M. A., Saleem, F., Farooqui, M. \& Khan, T. M. (2015). Scope of Mix-Method Studies in Pharmacy Practice Research. Indian Journal of Pharmaceutical Education and Research; 49; 93-98.

Hermansyah, A., Sainsbury, E. \& Krass, I. (2016). Community Pharmacy and Emerging Public Health Initiatives in Developing Southeast Asian Countries: a Systematic Review. Health and Social Care in the Community; 24; e11$\mathrm{e} 22$.

Hermansyah, A., Sainsbury, E., \& Krass, I. (2018). Multiple Policy Approaches in Improving Community Pharmacy Practice: the Case in Indonesia. BMC Health Services Research; 18; 449.

Herzberg, F. I. (1966). Work and the Nature of Man. Cleveland: World Pub. Co.

Iorga, M., Dondaş, C., Soponaru, C. \& Antofie, I. (2017). Determinants of Hospital Pharmacists'
Job Satisfaction in Romanian Hospitals. Pharmacy; 5; 66.

Iqbal, M. S., Al-Saikhan, F. I., Ahmed, N. J. \& Iqbal, M. Z. (2020). Predictors of Job and Workplace Satisfaction among Community Pharmacists. Journal of Pharmaceutical Research International; 32; 78-85.

Janahiraman, S. \& Paraidathathu, T. (2007). Job Satisfaction among Malaysian Pharmacists. Jurnal Sains Kesihatan Malaysia; 5; 79-90.

Karina, P. (2011). Analisis Faktor Motivasi dan Tingkat Kepuasan Kerja Petugas Farmasi di RS PHC Surabaya. Skripsi; Fakultas Kesehatan Masyarakat Universitas Airlangga, Surabaya.

King, M. A., Sav, A., McMillan, S. S., Wheeler, A. J., Kendall, E., Whitty, J. A. \& Kelly, F. (2012). Community Pharmacy in Australia: a Health Hub Destination of the Future. Research in Social and Administrative Pharmacy; 9; 863875.

Mcmillan, S. S., Kelly, F., Sav, A., King, M. A., Whitty, J. A. \& Wheeler, A. J. (2014). Consumer and Carer Views of Australian Community Pharmacy Practice: Awareness, Experiences and Expectations. Journal of Pharmaceutical Health Services Research; 5; 29-36.

Mihm, D. J., Mihm, L. B., Lonie, J. M. \& Dolinsky, D. (2011). Selected Perceptual Determinants of Pharmacy Students' Expected Job Satisfaction: a Pilot Study. Currents in Pharmacy Teaching and Learning; 3; 185-191.

Munger, M. A., Gordon, E., Hartman, J., Vincent, K., \& Feehan, M. (2013). Community pharmacists' occupational satisfaction and stress: A profession in jeopardy? Journal of the American Pharmacists Association; 53; 282-296.

Nilugal, K. C., Kaur, M. J., Molugulu, N., Ethiraj, U. R., Arief, M., \& Chittur, A. I. (2016). Patients' attitudes and satisfaction towards community pharmacy in Selangor, Malaysia. Le Pharmacien Hospitalier et Clinicien; 51; 210-221.

Nyame-Mireku, M. N. (2012). Determinants of Job Satisfaction among Hospital Pharmacists and Their Intent to Leave Using Herzberg's Two-Factor Theory. Dissertation; School of Business and Technology Capella University, Minneapolis.

Mott, D. A., Doucette, W. R., Gaither, C. A., Pedersen, C. A. \& Schommer, J. C. (2004). Pharmacists' Attitudes toward Worklife: Results from a 
National Survey of Pharmacists. Journal of the American Pharmacist Association; 44; 326-336.

Murawski, M. M., Payakachat, N. \& Koh-Knox, C. (2008). Factors Affecting Job and Career Satisfaction among Community Pharmacists: a Structural Equation Modeling Approach. Journal of the American Pharmacists Association; 48; 610-620.

Olson, D. S., \& Lawson, K. A. (1996). Relationship between hospital pharmacists' job satisfaction and involvement in clinical activities. American Journal of Health-System Pharmacy, 53(3), 281284.

Omar, K., Halim, M. A. S. A., Yusoff, Y. M., Ahmad, A. \& Ibrahim, R. Z. A. R. (2018). Assessing Intention to Leave Among Public Hospital Nurses in Malaysia. Journal of Fundamental and Applied Sciences; 10; 294-305.

Phua, G. S. Y., Teoh, C. J., Khong, L. B., Baba, B., Lim, C. W., Koh, W. L., Rhazi, N. A. M. \& Ayob, N. C. (2017). The Satisfaction and Perception of Intern Pharmacists Towards Their Training in Government Hospitals in the Northern Region of Malaysia. Pharmacy Education; 17; 15-23.

Ralph, D. A. \& Langenbach, M. (1987). Oklahoma Pharmacists' Explanations of Professional Satisfaction and Dissatisfaction. Journal of Pharmaceutical Marketing \& Management; 1; 81-95.

Rijaluddin, M. K., Utami, W., Othman, Z., Puspitasari, H. P., Rahem, A., Sukorini, A. I. \& Hermansyah, A. (2020). Exploration of Barriers Affecting Job Satisfaction Among Community Pharmacists. Journal of Basic and Clinical Physiology and Pharmacology; 30; 1-7.

Sains, J. (2012). Job Satisfaction among Malaysian Pharmacists. Jurnal Sains Kesihatan Malaysia (Malaysian Journal of Health Sciences); 5; 7990.
Schafheutle, Ellen I., Hassell, K. \& Eden, M. (2009). Workload Pressure among Recently Qualified Pharmacists: an Exploratory Study of Intentions to Leave the Profession. International Journal of Pharmacy Practice; 17; 181-187.

Schommer, J. C., Gaither, C. A., Doucette, W. R., Kreling, D. H. \& Mott, D. A. (2018). Associations between Work Activity and Work Setting Categories and Dimensions of Pharmacists' Quality of Work Life. Pharmacy; 6; 62.

Seston, E., Hassell, K., Ferguson, J. \& Hann, M. (2009). Exploring the Relationship Between Pharmacists' Job Satisfaction, Intention to Quit the Profession, and Actual Quitting. Research in Social and Administrative Pharmacy; 5; 121132.

Shah, S. H. A. \& Beh, L. S. (2016). The Impact of motivation enhancing practices and Mediating Role Of Talent Engagement on Turnover Intentions: Evidence from Malaysia. International Review of Management and Marketing; 6; 823-835.

Simada Binfar (2020). Jumlah Apotek di Jatim Tahun 2018 by Simada Binfar. http://simada.binfar.kemkes.go.id/admin/jatim. (Accessed: 15 Januari 2020).

Thakur, S. J. \& Bhatnagar, J. (2017). Mediator Analysis of Job Embeddedness: Relationship between Work-Life Balance Practices and Turnover Intentions. Employee Relations; 39; 718-731.

$\mathrm{Xu}, \quad$ T., Wu, T. J. \& Li, Q. Q. (2018). The Relationships Between Job Stress and Turnover Intention Among Tour Guides the Moderating Role of Emotion Regulation. Journal of Interdisciplinary Mathematics; 21; 409-418. 